\title{
Reflection of the Baltic Sea Lithuanian nearshore bottom peculiarities in the historical maps
}

\author{
Rimas Žaromskis ${ }^{1}$, \\ Saulius Gulbinskas ${ }^{2}$ \\ ${ }^{1}$ Coastal Research and Planning Institute, \\ Vilhelmo Berbomo St. 10, \\ LT-92219 Klaipèda, Lithuania \\ E-mail: rimas.zaromskis@cablenet.lt \\ ${ }^{2}$ Open Access Centre for Marine Research, \\ Klaipeda University, H. Manto St. 84, \\ LT-92294 Klaipéda, Lithuania \\ E-mail: saulius.gulbinskas@ku.lt
}

Žaromskis R., Gulbinskas S. Reflection of the Baltic Sea Lithuanian nearshore bottom peculiarities in the historical maps. Geologija. Geografija. 2015. T. 1(4). ISSN 2351-7549.

Using the bathymetry information available from historical maps, the underwater slope of the Baltic Sea in the Lithuanian area of the shore is analysed south and north of the Klaipeda harbour. For this purpose, the old depth measurements have been converted into the metric system and cross profiles of the nearshore drawn, as well as, on this basis, the diagrams for the 3,5,7 and $10 \mathrm{~m}$ depth points have been constructed. The depth data from the maps compiled in 1743 , 1855,1875 and 1913 have been analysed. These periods correspond to specific conditions of the shore zone morpho- and litho-dynamics. In 1743 there was no beach protecting the dune ridge on the Curonian Spit, and sand was driven by wind from the shore zone to the large dunes. There were no hydro-engineering structures in the Klaipeda harbour; therefore nothing impeded sand migration along the shore. In 1855 the shores of the Klaipeda channel were fixed, but there were no harbour piers yet. In 1875, the piers were freshly built and a beachprotecting dune ridge partly formed. In 1913, this dune ridge was already finished and the Klaipeda port was fully functioning with 5-6 m depths at the port gates. Conclusions are made about the former bottom relief during different stages of the nearshore evolution and about the conditions which caused its changes.

Key words: historical maps, bottom relief, nearshore evolution, coastal protection, hydrotechnical constructions, Baltic Sea, Curonian Spit

\section{INTRODUCTION}

The seacoasts being created by interaction of three spheres - lithosphere, hydrosphere and atmosphere - are notable for great dynamicity of nature processes. Since the seacoasts are attributed to the most densely populated areas of the Earth, beside the nature processes, there is also a very intense human activity related to reconstructions of the living environment, urbanisation, transport industry, exploitation of sea and shore resources, etc. By accommodating the coast for living, changing river mouths, erecting and reconstructing harbours, as well as changing the nearshore sediment transport balance, environmental conflicts occur in great numbers. Implementing various projects and trying to solve the environmental conflicts, a need to get kowledge about the former natural state of a coast or a nearshore occurs rather often. Such a reference point enables to assess a real summarised scale of changes caused by human impact and realise how certain projects implemented historically affected the natural systems.

The result of this interaction between the nature processes and the human impact is conspicuously manifested in the south-eastern shore zone of the Baltic Sea nowadays. The anthropogenic 
invasion into this nature complex started in the 18 th century and proceeds further with intensifying speed. The construction of ports, forestation and transformation of coasts, fixing eroded shores, artificial interference into the natural nearshore drift balance took place (Žaromskis, 2001). Sooner or later, a question is raised for the society: Where is the initial reference point that would help to reveal the scale of human impact and provide valuable lessons.

In recent years a number of works addressing the topic of nearshore morphogenesis of the southeastern Baltic have been published, which examined the tendencies of Lithuanian coastal zone modern lithodynamics and bottom relief formation (Bitinas et al., 2005; Jarmalavičius, Žilinskas, 2006; Žilinskas, Jarmalavičius, 2007; Žaromskis, Gulbinskas, 2010; Bagdanavičiūtė et al., 2012). Still, all these studies have covered not only natural processes but also the situation determined by the human activities, especially the impact of Klaipeda port hydrotechnical structures. The impact of the Klaipeda port was analyzed in the individual studies of I. Korobova (Korobova, 1969; 1971). The historical analysis of the port breakwaters impact on the changes in coastal bottom topography was completed by R. Knaps (Knaps, 1952; 1966) and E. Červinskas (Červinskas, 1959; 1991).

The present paper is aimed at the analysis of variations in the sea nearshore bottom relief under almost natural conditions in the past and under the transformations going on at the northern part of the Curonian Spit (Kuršiu Nerija), where the dune ridge is being stabilised, the shores of the Klaipeda channel fixed by engineering means and harbour piers built. The authors used the cartographic material compiled from the mid 18th to the beginning of 20th century.

\section{MATERIALS AND METHODS}

Old cartographic material is used in the present article beside the nearshore morphometry data obtained by modern methods. Among the old cartographic documents, a particular attitude is given to the map Strand Carte des Königreichs Preussen See Küste von der Danziger Grentze bey Polske, bisz an die Sameitsche Grentze bey Polangen published by Johann W. Suchodoletz in 1743 .
Although this map shows the shoreline contour marked only approximately, but at the Lithuanian shores, the measurement profile base points are given at 500 Prussian rods, i. e. at 1883 metres (1 reinlandische Ruthe or a Prussian rod is $3.766 \mathrm{~m}$ ). The distances had been measured by a special marked wire (Roedder, 1908), and measurement points in all profiles were at 6,12 , $25,50,75,100$ and 125 rods from the shore, i. e. at $22.6 \mathrm{~m}, 45.2 \mathrm{~m}, 94.1 \mathrm{~m}, 188.3 \mathrm{~m}, 282.4 \mathrm{~m}$, $376.6 \mathrm{~m}$ and $470.75 \mathrm{~m}$ from the shoreline. Depths had been measured from a boat by hand lead and fixed as Prussian feet (1 Preussische Fuss is $0.31185 \mathrm{~m}$ ) (Červinskas, 1978). The map contains also the measurement data provided (Fig. 1). So, the data converted into metres enabled to draw profiles as deep as $5 \mathrm{~m}$; and using interpolation between the measurement points, an approximate view of the bottom relief is obtained.

These measurements by J. W. Suchodoletz are especially valuable because they were done in the 18th century, when the beach sand on the Curonian Spit was freely driven by the wind into large dunes thus, very likely, influencing the balance of sand drift along the underwater slope.

The sea nearshore relief in the first half of the 19th century is reflected in the map from the Prussian sea atlas published in 1840-1841 based on detailed measurements done in 18341840 (Červinskas, 1978). In 1855, the British Admiralty issued the chart Coast of Prussia at a scale of 1:100 000. The 1840-1841 map and its later versions had been compiled at the time when there were no piers in the Klaipeda harbour, because their construction had been going from 1834 to 1878 . This map reflects the lithodynamic situation when the underwater drift could migrate along the shore length at the Klaipeda channel almost without hindrance. The formation of the so-called protective beach dune ridge was finished at that time only on the southern part of the Curonian Spit (Wichdorff, 1919; Žilinskas et al., 2001). The map is notable for the abundance of measurement points. The depth isolines are drawn at 6 nautical feet, as well as 5 and 10 rods, i. e. $1.883,9.415$ and $18.83 \mathrm{~m}$. As deep as 6 feet, the isolines are given in feet, and deeper, in rods. To reflect better potential obstacles for navigation, the measurement profiles as 


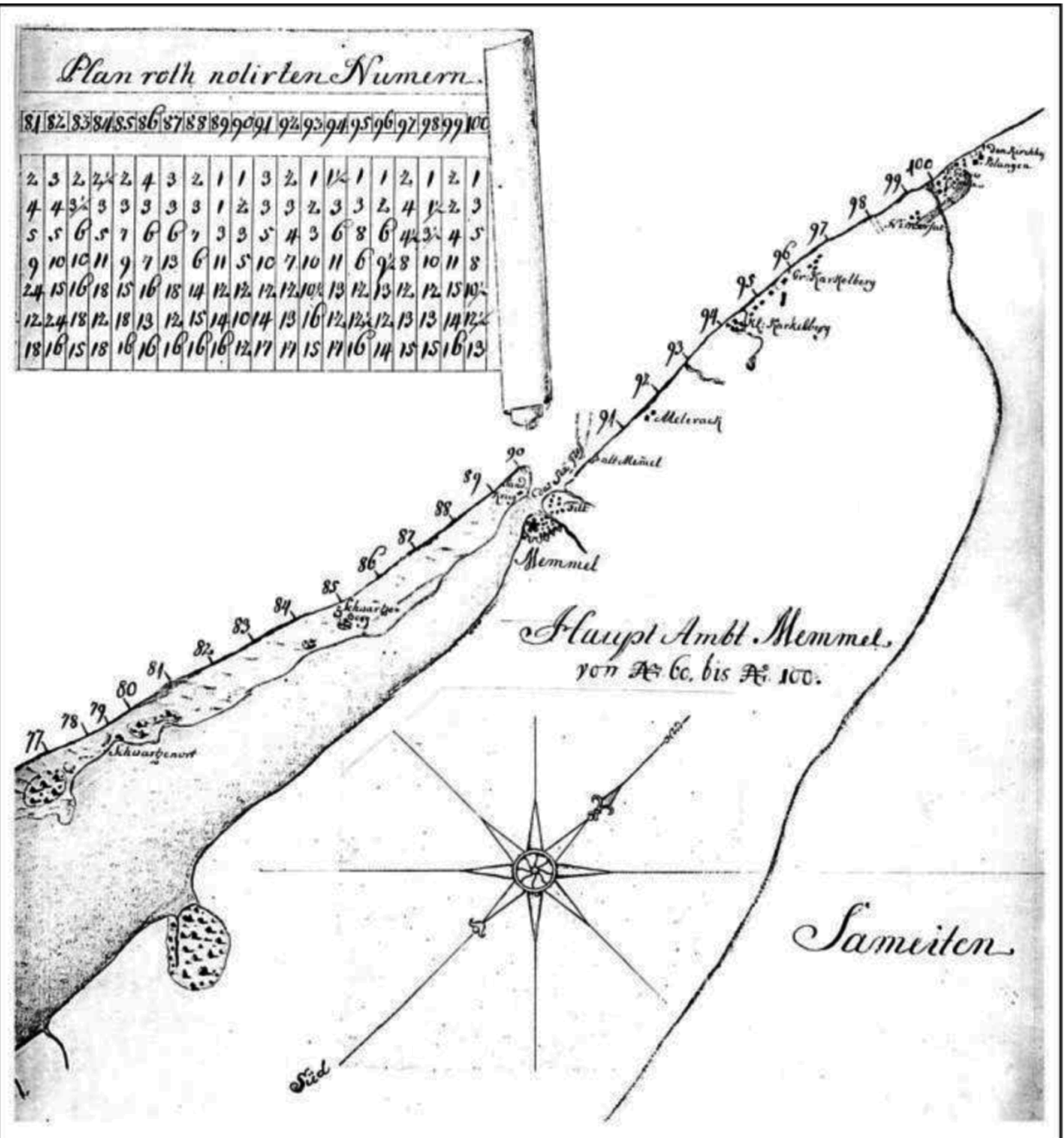

Fig. 1. A fragment from the map Strand Carte des Königreichs Preussen See Küste von der Danziger Grentze bey Polske, bisz an die Sameitsche Grentze bey Polangen compiled in 1743 by J. W. Suchodoletz (personal archive of E. Červinskas)

deep as 6 feet were drawn at 15 " of latitude, i. e. by $463 \mathrm{~m}$, stretching into the sea at an angle of $45^{\circ}$ and making small rectangles (Fig. 2). Restoring the bottom relief according to the profiles perpendicular to the shore at 30 latitude seconds, the depths between the points are determined by interpolation from the nearest measurement point data.

The situation at the harbour of Klaipeda in the second half of the 19th century is reflected in the map Deutsche Küste Preussen at a scale of 1:150 000 based on the data of measurements done in 1875 as well as the map Hafen von Memel (1:25 000) compiled on the same basis; they both were published in 1877 . The maps depicted the environment around the Klaipeda harbour just after the piers had been constructed.
The map at a scale of 1:25 000 shows the position of the northern and southern piers being respectively at the meridians of $19^{\circ} 55^{\prime}$ and $19^{\circ} 57^{\prime} 20^{\prime \prime}$. At that time, the northern and southern piers were extending into the sea by 217 and $340 \mathrm{~m}$, respectively. The cross profiles of the nearshore have been drawn according to the interpolated depths from the nearest measurement points at 1 latitude minute.

The effect of coastal defence measures in the 19th century and the piers of the Klaipeda harbour on the bottom relief in the nearshore is reflected in the nautical chart Hafen von $\mathrm{Me}$ mel (1:20 000) compiled in 1913. The data of this map are used to analyse the $1.5 \mathrm{~km}$ northward nearshore length and $6 \mathrm{~km}$ length southwards from the Klaipeda harbour piers. 


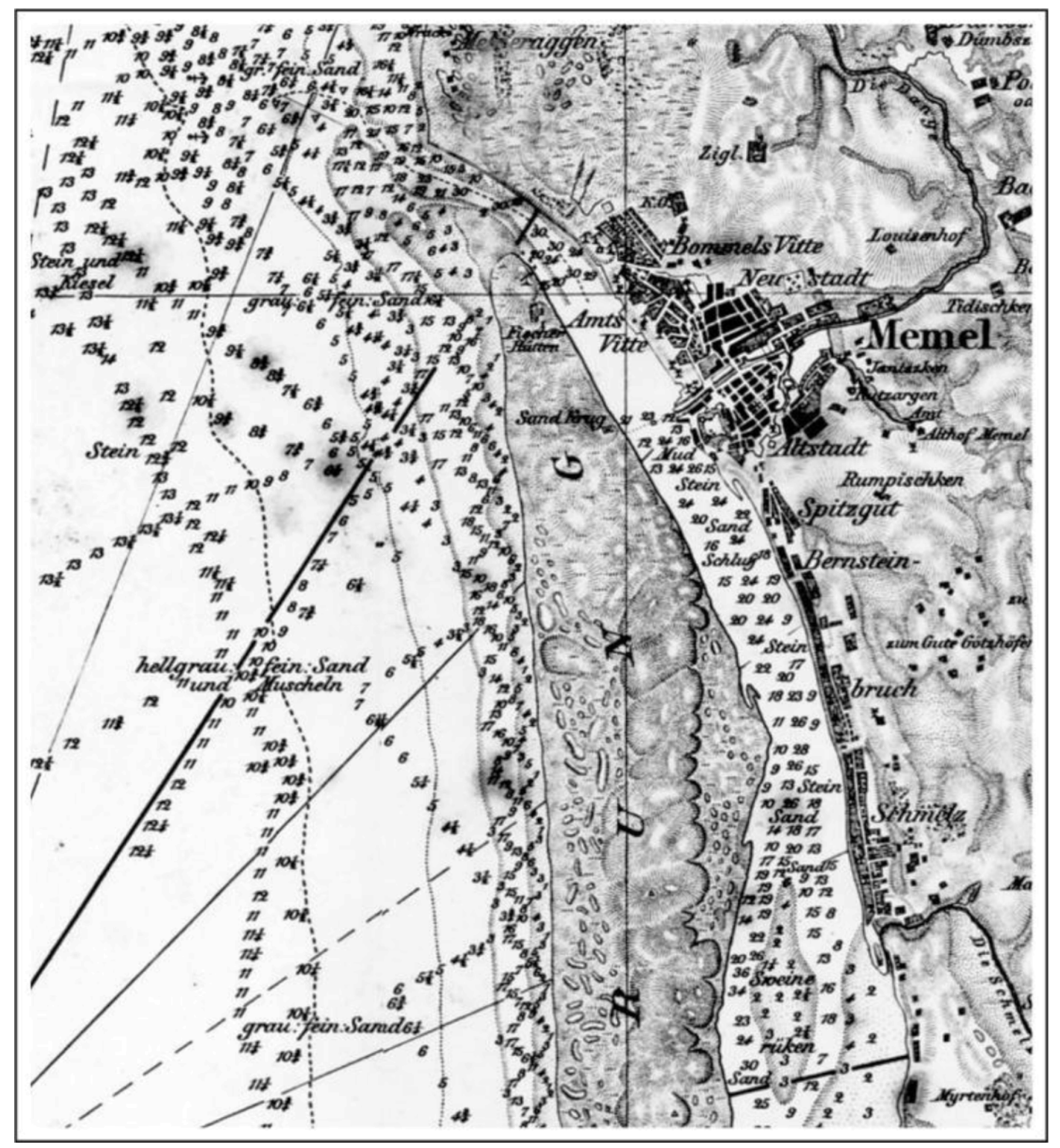

Fig. 2. A fragment from the 1840-1841 Prussian sea atlas with the Klaipeda channel and the sea nearshore stretching southwards (personal archive of E. Červinskas)

Although the maps used for the present paper differed in their scale and details, their analysis enabled to reveal general peculiarities of the bottom relief between the measurement points by determining distances from the depths of 2, 3, 5, 7 , and $10 \mathrm{~m}$ closest to the shore. Assuming that the bottom surface profiles are oblique lines joining the shoreline to the same depth points located at different distances from the shore, one can make oblique triangles and assess their area as a change in the sediment stratum area, as determined from the maps of different time periods. Having the distances between the cross profiles of the nearshore, the quantification of accumulated sediments can also be assessed.

\section{CHANGES IN NEARSHORE BOTTOM RELIEF FROM 1743 TO 1913}

The cross profiles of the Curonian Spit nearshore bottom constructed from the data of 1743 show very different degrees of relief dissection that increases with a distance southwards from the Klaipeda channel. A similar tendency is also observed nowadays. Bars are becoming very high and very deep, troughs between the bars are formed in the nearshore at the middle part of the Curonian Spit south of Pervalka, 33-35 km south of the Klaipeda channel (Žaromskis, Gulbinskas, 2010). As for the 1743 measurement data, the maximum of bar parameters is observed 
closer to the channel, at 15-16 km from it (Fig. 3). Moreover, the underwater slope gradient is now significantly lower than that in the 18th century.

The measurements done by J. W. Suchodoletz also revealed rather significant differences in the underwater shore slope relief in the profiles close to the Klaipeda channel. The contrast between the profiles 89 and 90 is especially striking. So, if the profile 89 , situated at about $2 \mathrm{~km}$ south of the channel (see Fig. 1), has a $3.5 \mathrm{~m}$ depth at a $100 \mathrm{~m}$ distance from the shore, the profile 90 being the last on the Curonian Spit has only a $1.2 \mathrm{~m}$ depth at this distance. In spite of the flatness of the nearshore at the southern bar shallow, the Kopgalis profile has a trough between the bars at a $300 \mathrm{~m}$ distance and a $0.6 \mathrm{~m}$ high flat-sloping sand ridge (Fig. 4). In accordance to the map, the southern bar shallow should extend as far as $1 \mathrm{~km}$ from the profile 90 site. This is shown by a NNW direction of the harbour access fairway.

The 18th century data show that the nearshore south of the settlement of Melnrage was rather deep, with no signs of bars. Two or even three bars are seen only in the profile 93 , about $9 \mathrm{~km}$
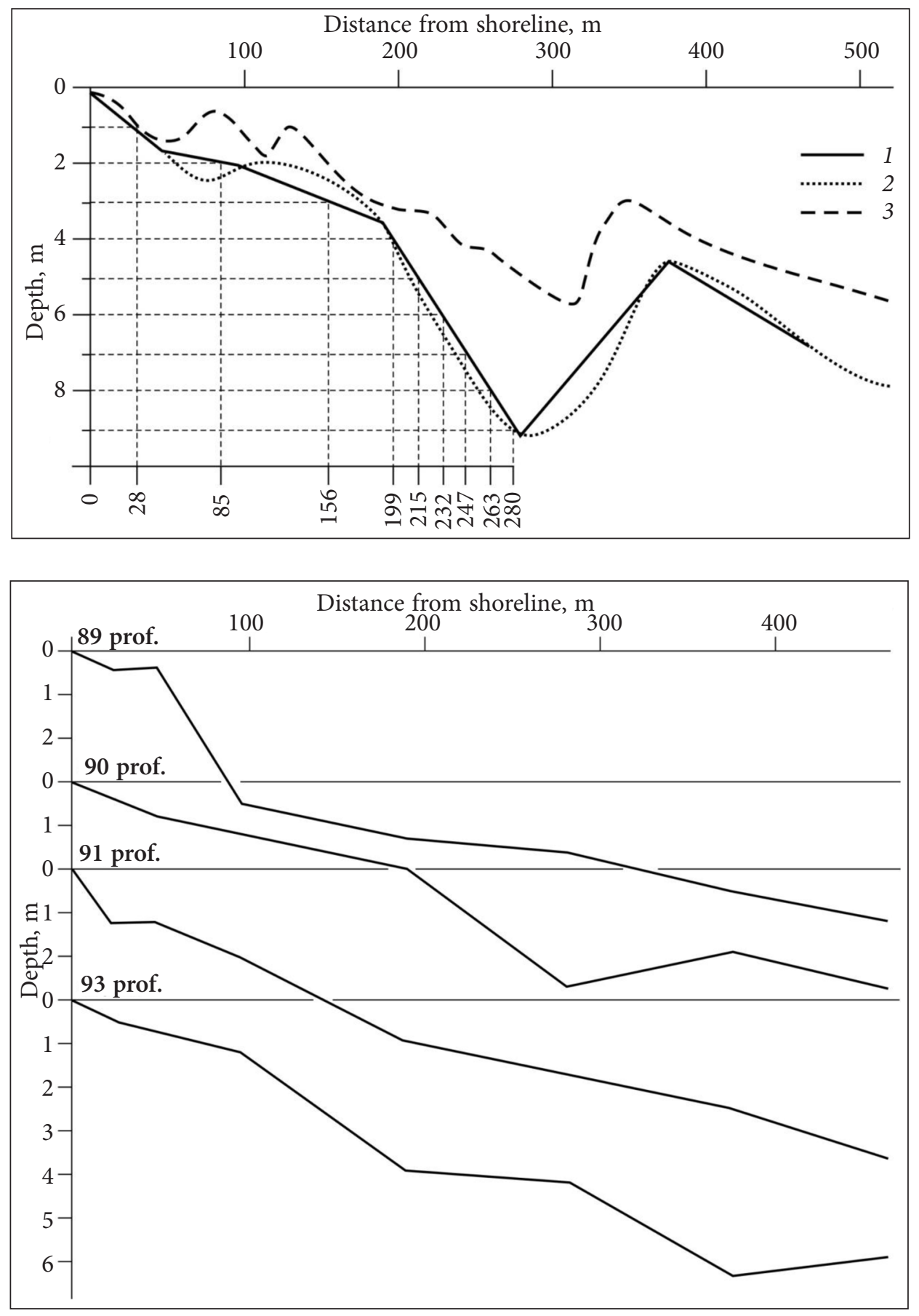

Fig. 3. Comparison of nearshore bottom relief profiles at $15 \mathrm{~km}$ south of the Klaipeda channel measured in 1743 and 2002. 1 - after the J. W. Suchodoletz map data; 2 - after the measurements in 2002; 3 - a hypothetic profile possible in the 18 th century

Fig. 4. Nearshore bottom relief profiles drawn after the J. W. Suchodoletz map data. Profiles 89 and 90 - at the northern part of the Curonian Spit, profiles 91 and 93 - north of the Klaipeda channel. The situation of profiles given in Fig. 1 is shown 
north of Klaipeda. If compared to the present-day situation, when this length of the underwater slope has a very small mass of sand (Žaromskis et al., 2010), there was a well-developed sandy accumulative nearshore in the 18th century.

The lithodynamic situation of the 18th century nearshore south and north of the Klaipeda channel is well reflected by a scheme showing the distribution of 2, 3, 4 and $5 \mathrm{~m}$ depths in regard to the shore (Fig. 5). Differently than the current situation, the sea nearshore north of Klaipeda was significantly shallower. The distances from the shoreline to the corresponding depth isolines north of Klaipeda are significantly longer than in the nearshore of the Curonian Spit. Hence, the accumulations of sand deposits on the underwater slope north of the channel are also bigger. A single place, where the $5 \mathrm{~m}$ depth line stands out to the sea beyond the $300 \mathrm{~m}$ zone, is the present-day region of Smiltyne - Kopgalis (Fig. 5). The distribution of depths shows that the northward longshore drift had not discharged at a distal end of the Curonian Spit, as it is now (Žaromskis, Gulbinskas, 2010). However, active discharge of the drift had occurred at a $9 \mathrm{~km}$ longshore length north of the channel. The intensification of drift accumulation north of the channel seems to be caused by a local southward transport of lithogenic material due to waves caused by weak or moderate western and northwestern winds (Žaromskis, Gulbinskas, 2011).

Another map published in 1855 at a scale of 1:100 000 already reflects the situation affected by the man. By forming the protective dune ridge, the wind driven sand transport from the beach to the large dunes had stopped. The stabilisation of shores of the Klaipeda channel by hydro-engineering structures had started, but the construction of sea-going piers had not been finished yet. According to the map compiled in 1855, the profiles made at 30' N (Fig. 6) show the presence of well-developed underwater bars in the nearshore. Going from the south to the north, the bars disappear only at the Klaipeda channel in the area of the southern bar shallow newly being reformed. At the latitude $55^{\circ} 43^{\prime} 10^{\prime \prime} \mathrm{N}$, the underwater slope profile becomes step-wise. Such a step-wise bottom profile has been fixed also in 1973-1974 (Žaromskis, 1974), and it is assumed to be a result of the excessive accumulation of sediments and wakening of the longshore drift flow. The profiles south of the bar shallow show that in the first half of the 19th century, there was still a rather well developed longshore drift at a 4-5 km length from the harbour gate, but the nearshore had already started getting features characteristic of a typical accumulative shore. There were no such steep slopes of the nearshore bottom left as those determined in 1743 for the profile 89 (see Fig. 4).

North of the Klaipeda channel, at $55^{\circ} 44^{\prime} \mathrm{N}$, the nearshore was rather deep, since the $3 \mathrm{~m}$ depths were observed very close to the shore (Fig. 6). In spite of a deeper bottom, the presence of an underwater bar and a flat underwater slope (especially within the zone between 500 and 900 metres from the shore) shows occurrence of sediment resources still sufficient to form the northern bar shallow. Going northwards of the Klaipeda channel, the part of the underwater slope being close to the shore becomes more flat $\left(55^{\circ} 456^{\prime}\right)$, but the slope becomes steeper from a $2-3 \mathrm{~m}$ depth. Such a rather flat un-

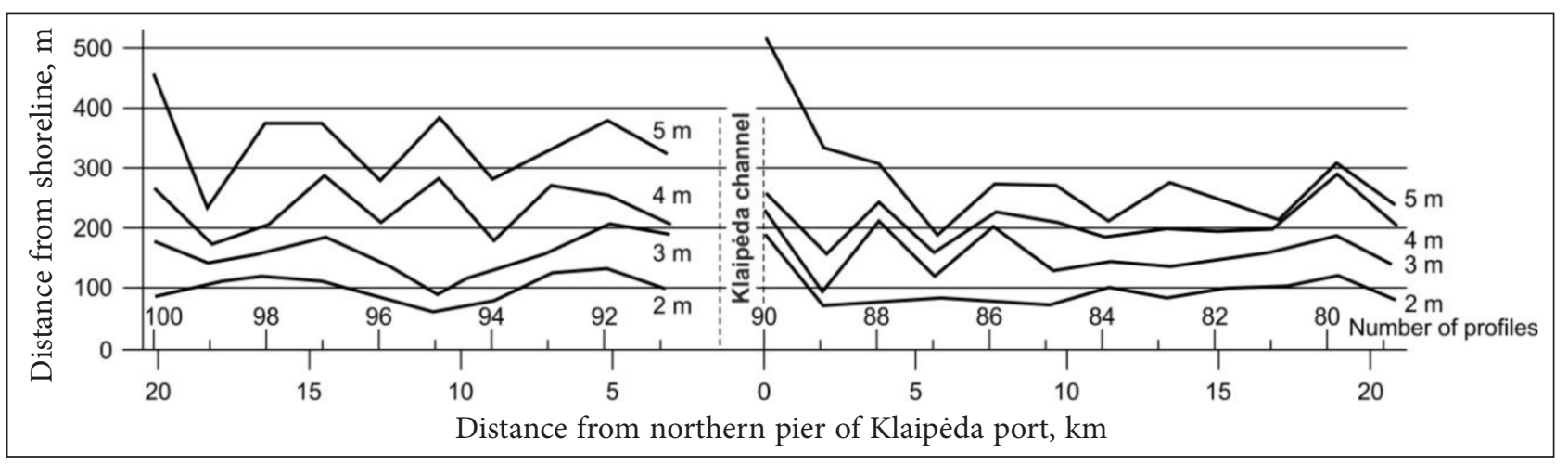

Fig. 5. Distribution of depths (distances of 2, 3, 4 and $5 \mathrm{~m}$ depth isolines from the shoreline) north and south of the Klaipeda channel after the map by J. W. Suchodoletz issued in 1743. The situation of profiles given in Fig. 1 is shown 


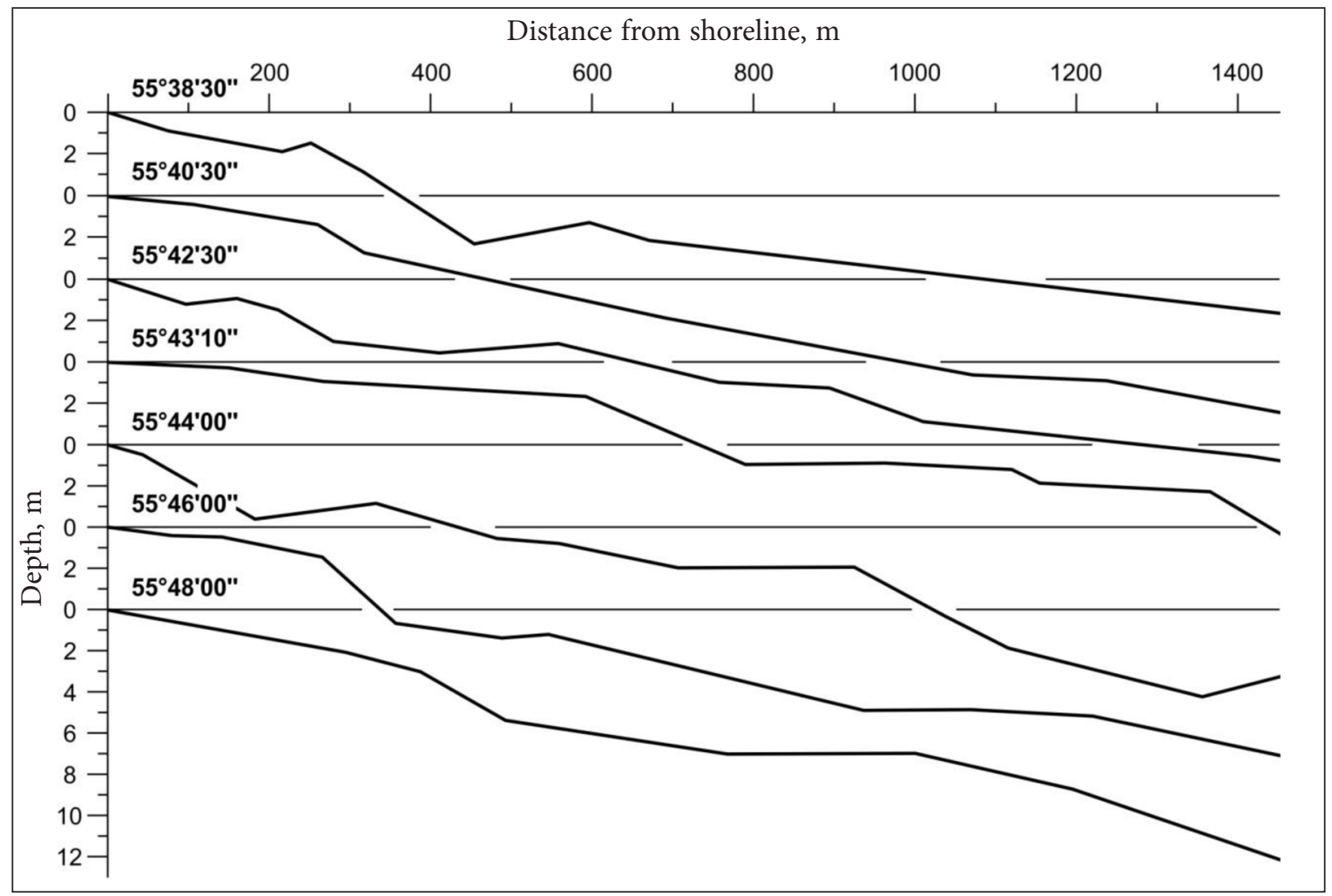

Fig. 6. Cross profiles of the nearshore south and north of the Klaipeda channel as drawn after the map compiled in 1855 at a scale of 1: 100000

derwater slope remains within the $8 \mathrm{~km}$ length of the shore as far as the present-day village of Karklè. So, the sites, where now shore erosion is observed and the underwater slope prevailingly consists of till formations and cobble (Žaromskis et al., 2010), contained mainly sand by mid-19th century. The bottom slopes becoming steeper at a $7 \mathrm{~m}$ depth in the profile $55^{\circ} 48^{\prime} \mathrm{N}$ show that till loam could be exposed.

The analysis of the map of 1855 showed that, both south and north of the Klaipeda channel, the nearshore bottom relief as deep as $5 \mathrm{~m}$ differs substantially from that observed in 1743 . If a $3 \mathrm{~m}$ depth at the southern side of the harbour in 1743 was at about $150 \mathrm{~m}$ from the shore, the same $3 \mathrm{~m}$ depth in 1855 was already at $300 \mathrm{~m}$ from the shoreline, while the $5 \mathrm{~m}$ depths, which were at $250-300 \mathrm{~m}$ distances from the shore, shifted seawards by $100-$ $150 \mathrm{~m}$ (Fig. 7). The seaward shift of depth is also observed for the depths measured in 1743. The southern bar shallow showed up more significantly, and the distances to the same depths north and south of the Klaipeda channel evened up in fact.

The map compiled in 1875 at a scale of 1 : 150000 depicts an even more changed bottom re- lief of the sea nearshore. South of the harbour piers the bottom became substantially more flat than that in the area north of the piers (Fig. 8). Average distances from the shoreline to the depths of 2, 3, 5, 7 and $10 \mathrm{~m}$ north and south of the piers get closer to the shore, if compared to those of the map compiled in 1855.

Bottom slopes became steeper north of the harbour as far as the $3 \mathrm{~m}$ depths and south of the harbour as far as 3-7 $\mathrm{m}$ depths (Table).

These changes south of the harbour might be related to the construction of the southern pier (Žaromskis, 2008), since from 1855 to 1875 this pier was extended to $350 \mathrm{~m}$. In spite of the fact that the total accumulation of the sediments close to the harbour increased at a distance of $3-5 \mathrm{~km}$ from the southern pier, the depths of 3, 5, 7 and $10 \mathrm{~m}$ shifted closer to the shore, hence, the bottom slope became steeper. Due to the extension of the pier and accumulation of sediments at a distal part of the sand spit, the shoreline was rapidly shifting seawards. Nevertheless, the sediment mass on the underwater slope was not growing so rapidly as at the shoreline, therefore, bottom sloping was inevitably increasing. Moreover, the current velocities 


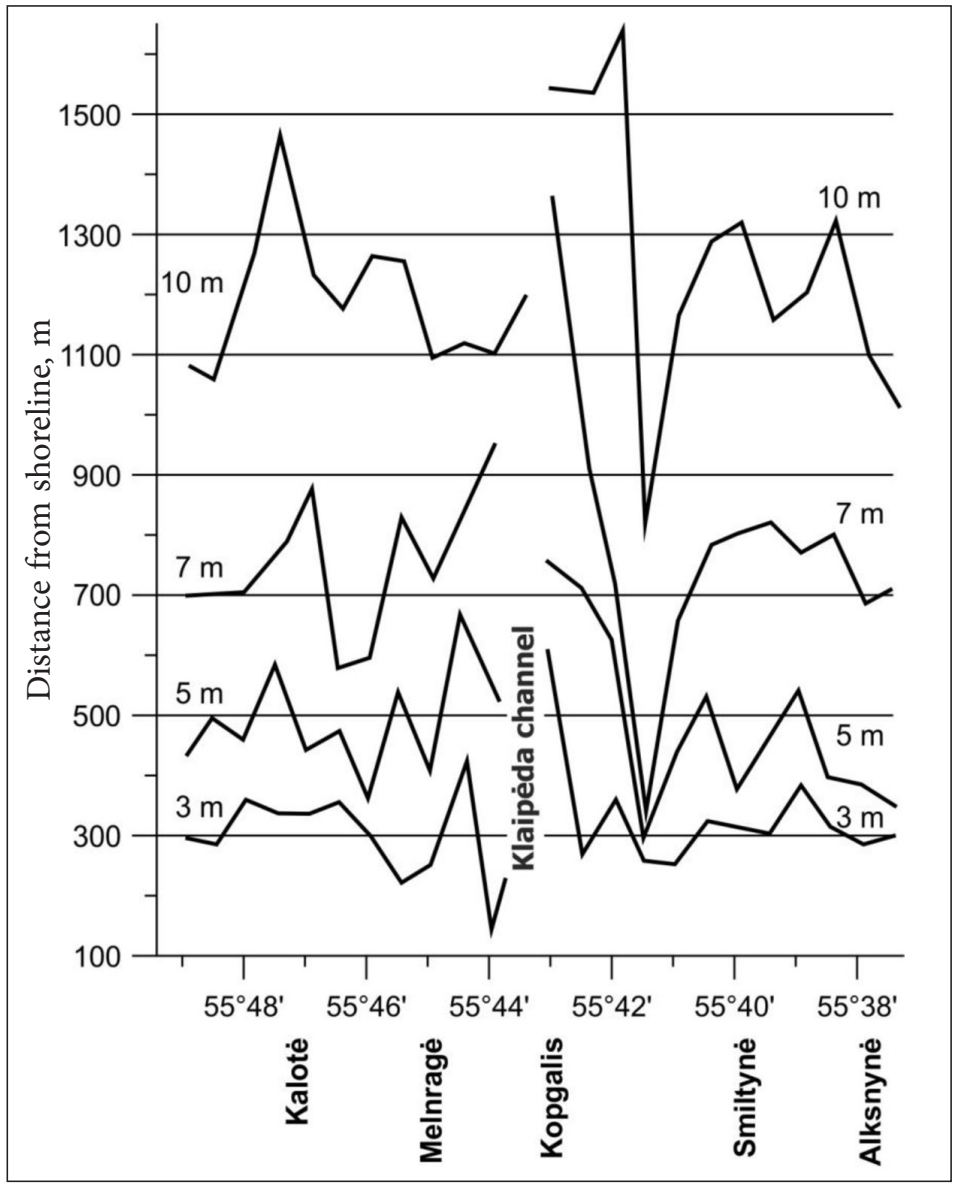

Fig. 7. Distribution of depths (distances from shoreline to 3, 5, 7 and $10 \mathrm{~m}$ depth isolines) in the cross profiles of the nearshore after the data from the map compiled in 1855

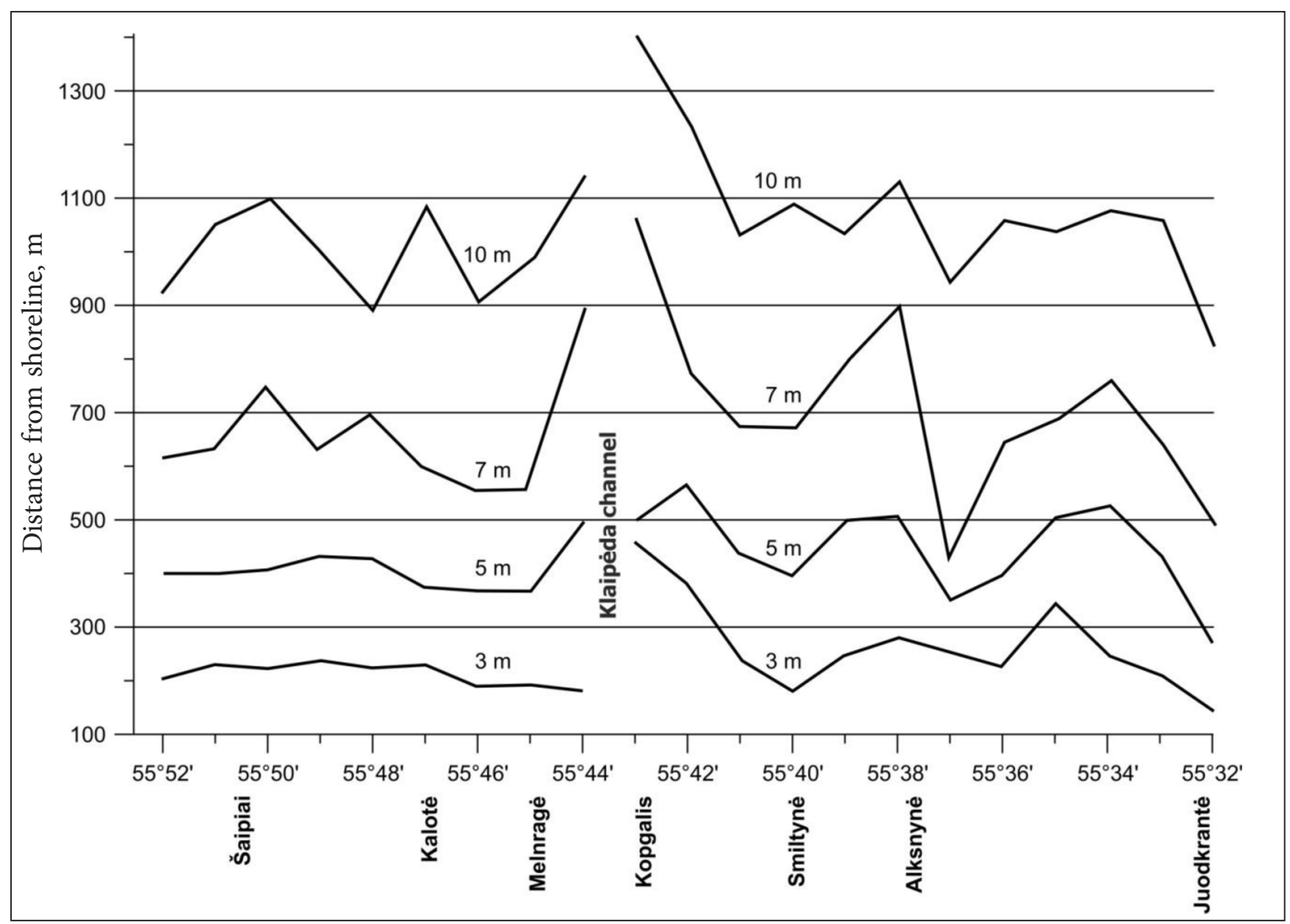

Fig. 8. Distribution of depths (distances from shoreline to 3, 5, 7 and $10 \mathrm{~m}$ depth isolines) in cross profiles of the nearshore after the measurements done in 1875 
Table. Distances from the shoreline to the corresponding depth isolines in the profiles $6 \mathrm{~km}$ north and south of the Klaipeda channel for different years

\begin{tabular}{|c|c|c|c|c|c|c|c|c|c|c|}
\hline \multirow{3}{*}{ Years } & \multicolumn{10}{|c|}{ Average distances $(\mathrm{m})$ from the shoreline to corresponding depths } \\
\hline & \multicolumn{5}{|c|}{ North of Klaipèda channel (harbour) } & \multicolumn{5}{|c|}{ South of Klaipèda channel (harbour) } \\
\hline & $2 \mathrm{~m}$ & $3 \mathrm{~m}$ & $5 \mathrm{~m}$ & $7 \mathrm{~m}$ & $10 \mathrm{~m}$ & $2 \mathrm{~m}$ & $3 \mathrm{~m}$ & $5 \mathrm{~m}$ & $7 \mathrm{~m}$ & $10 \mathrm{~m}$ \\
\hline 1743 & 119 & 187 & 342 & & & 105 & 162 & 333 & 802 & \\
\hline 1855 & 225 & 293 & 484 & 788 & 1202 & 315 & 362 & 565 & 805 & 1327 \\
\hline 1875 & 106 & 220 & 407 & 663 & 1011 & 129 & 302 & 482 & 752 & 1176 \\
\hline 1913 & 124 & 206 & 364 & 707 & 1205 & 144 & 223 & 452 & 664 & 1238 \\
\hline
\end{tabular}

bypassing the piers had to increase, thus, enhancing the bottom sediment transport from the underwater slope of the nearshore.

There is a presumption that such reformation of the bottom relief, after construction of piers, is also related to changes in the longshore drift. At the northward transport, the southern pier favoured accumulation of sediments on its windward side and did not allow southward sediment transport in the case of NW winds. The occurrence of a steeper nearshore bottom at the site $3 \mathrm{~km}$ south of the pier shows the impact of the then hydroengineering structure on the zone of the distal end of the Curonian Spit. A similar impact of the same pier at the turn of the 20th-21st centuries embraced already a $9 \mathrm{~km}$ length of the shore zone (Žaromskis, Gulbinskas, 2010).

A detailed character of the 1875 map enables to assess general sloping of the bottom for different depth zones, but it is not sufficient to determine the width of the underwater bars or their zones. However, the cross profiles of the nearshore at the latitudes of $55^{\circ} 46^{\prime}-48^{\prime} \mathrm{N}$ and distances of $700-800 \mathrm{~m}$ from the shore reveal the bottom zones which became steeper (Fig. 9). Nowadays, such 'breaks' in a bottom cross profile indicate outcropping till loam formations (Žaromskis, 2007).

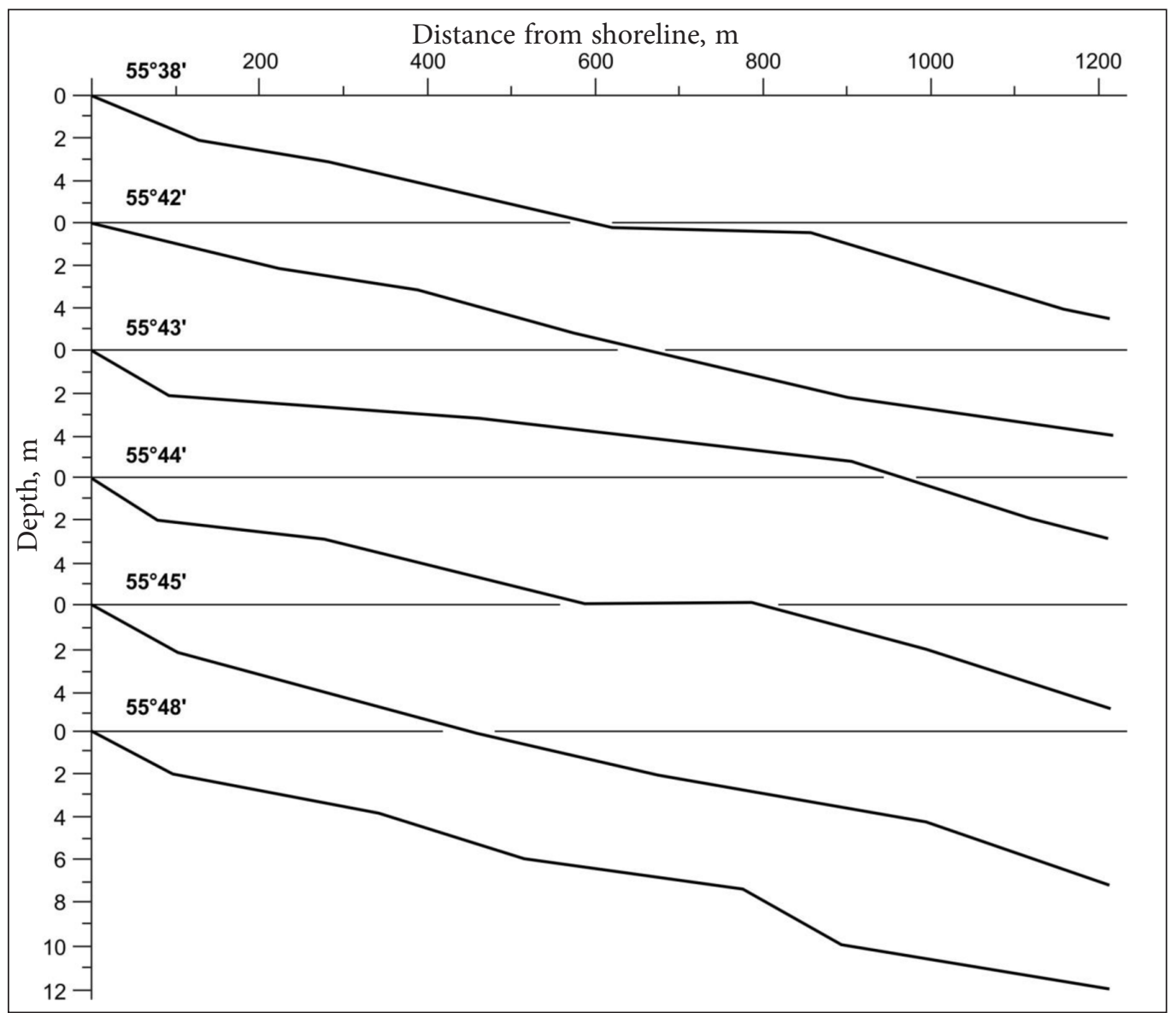

Fig. 9. Sea nearshore bottom profiles drawn after the depths given in the map compiled in 1875 
The map compiled in 1875 shows that the bar shallow 2.5-5 km north of the harbour becomes smaller, and due to sand accumulation waning, the area of the nearshore sand cover decreases and isobaths come closer to the shore. The changes in the shore zone in the 19th century, after the construction of piers in the Klaipeda harbour was over, had been assessed in a similar way by other authors (Žilinskas, 1998). The construction of piers changed the sea nearshore relief north of the harbour in a shore length of about $5 \mathrm{~km}$.

A rather more detailed picture of the nearshore bottom is seen in the nautical chart Hafen von $\mathrm{Me}$ mel compiled by Captain Hoffmann on the basis of measurements done in 1875 and issued in 1877 at a scale of 1:25 000 (Červinskas, 1978) (Fig. 10).

The 2 and $4 \mathrm{~m}$ isobaths drawn in this chart are crossed by harbour piers, while those of 6 and

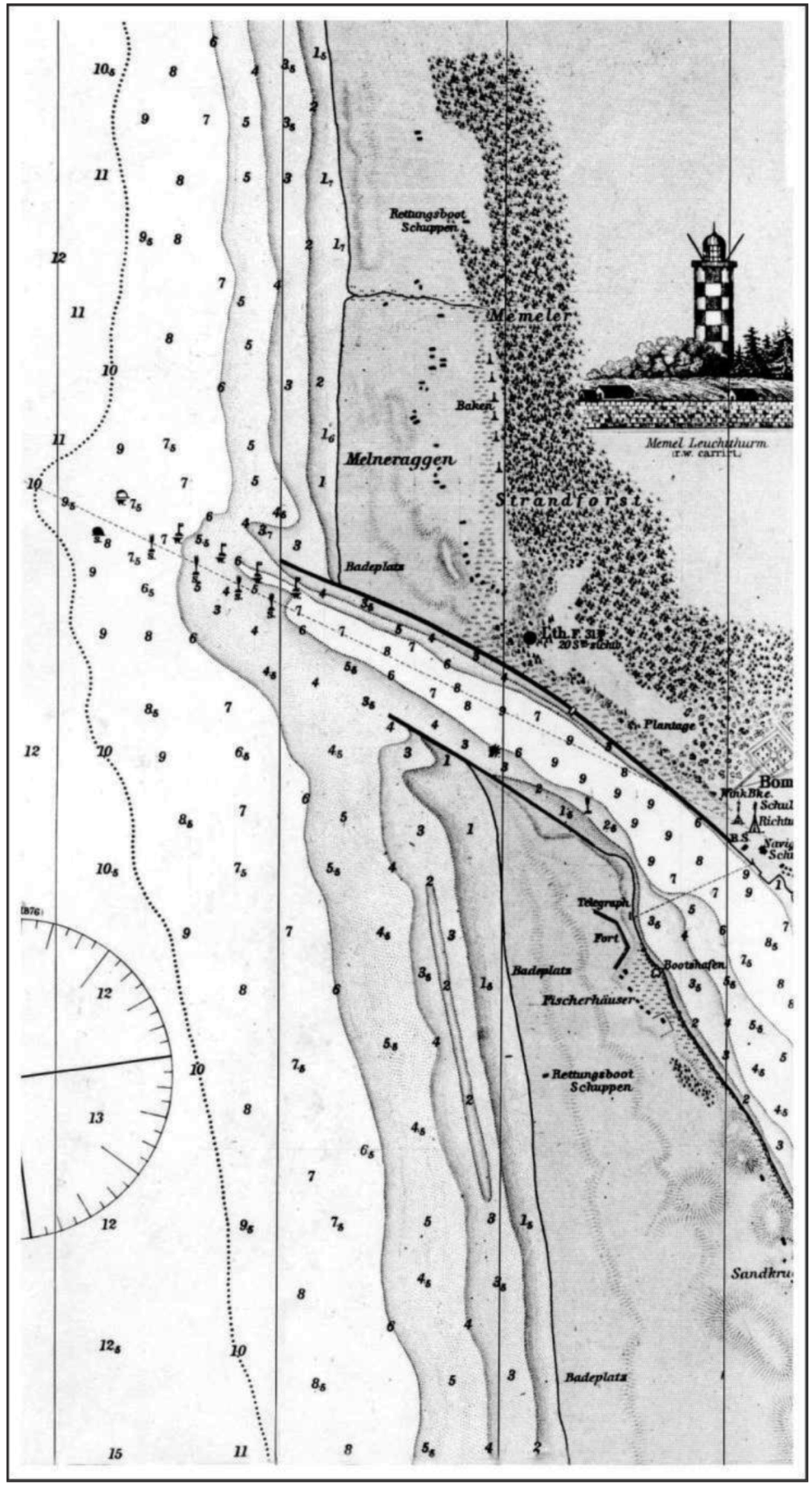

Fig. 10. A fragment of the chart Hafen von Memel compiled by Hoffmann and issued in 1877 
$10 \mathrm{~m}$ are softly curving but not interrupting. The cross bar shallow in front of the harbour gate contains 4-5 m depths marked; this shows that longshore drift even at average waves could pass by the newly built piers. An assumption can be made that the curving of the 6 and $10 \mathrm{~m}$ isobath is caused by water flow from the lagoon not by the current transporting sediments along the shore and passing by the piers. This chart also reflects some different peculiarities in nearshore morphology south and north of the piers. About $600 \mathrm{~m}$ south of the pier, the nearshore is seen to have an unbroken underwater bar extending along the shore, thus showing rich accumulation of sediments. At the same time, about $200 \mathrm{~m}$ north of the harbour, the isobaths of 2 and $4 \mathrm{~m}$ come closer to the shore, but there is no tendency of eastward shoreline retreat yet.

The impact of the Klaipeda port construction in the 19th century, as well as the related formation of a protective dune ridge on the Curonian Spit, on the nearshore bottom is reflected in the map Hafen von Memel issued in 1913 at a scale of 1:20 000. It presents a $9 \mathrm{~km}$ length of the Curonian Spit nearshore and about a $1.5 \mathrm{~km}$ long nearshore strip north of Klaipeda.

Comparing this map with the former one, some obscure circumstances of the pier construction should be taken into account. So, J. Sembritzki in his fundamental work about the 19th century Klaipeda (Zembrickis, 2004), its first edition had appeared in 1902, wrote that the southern and northern piers were finished, respectively, in 1880 and $1884 \mathrm{~m}$. However, E. Červinskas, after a detailed analysis of documentation related to the port construction, found that the southern pier was once more extended in 1901-1902 by $445 \mathrm{~m}$, i. e. to $1385 \mathrm{~m}$. Therefore, the bottom changes which took place from 1875 to 1913 should not be attributed to only natural processes in the nearshore that was adapting only to the hydro-engineering structures built before. The necessity to extend the southern pier seems to be caused by unstable depths in the pass for ships. The projected depth of $6.1 \mathrm{~m}$ (Žaromskis, 2008) often decreased to $5 \mathrm{~m}$ or even less (Knaps, 1952).

The map compiled in 1913 revealed that from 1875 the morphodynamic tendencies in the nearshore changed significantly when the sediment accumulation processes were replaced by bottom erosion and related increase in sloping (Fig. 11).

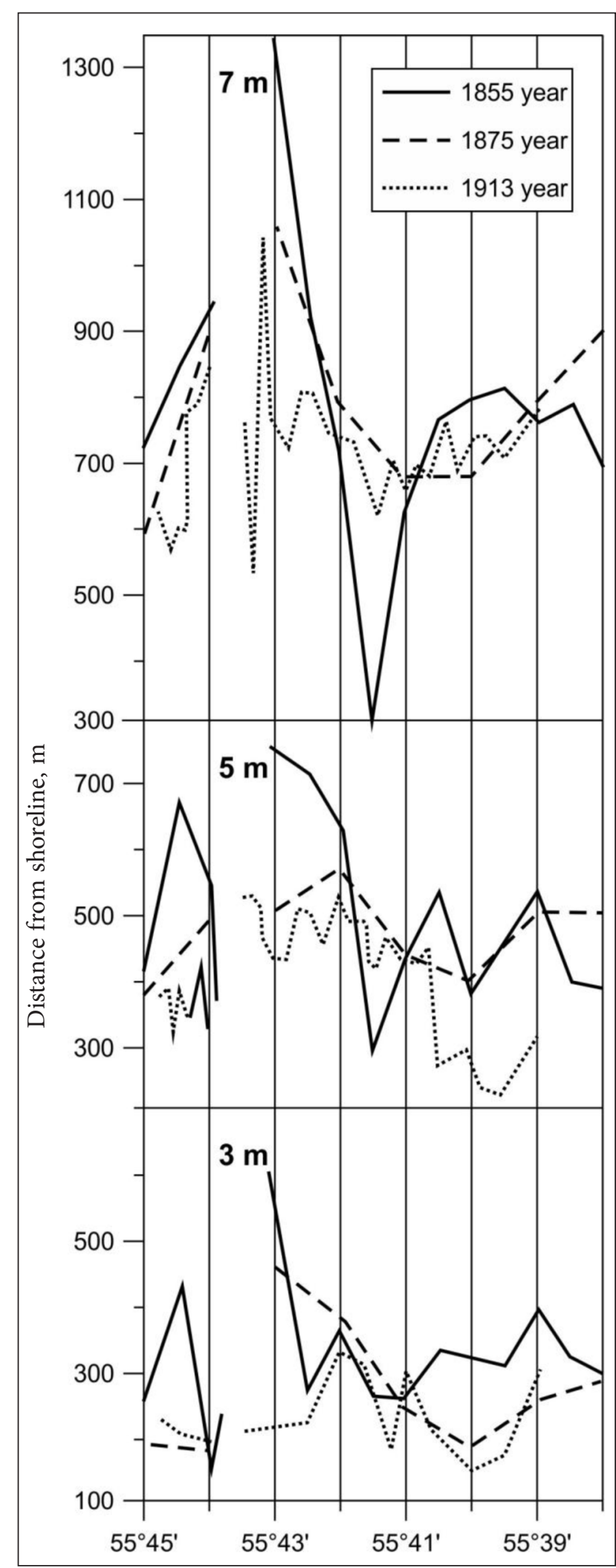

Fig. 11. Distances from the shoreline to the 3,5 and $7 \mathrm{~m}$ depth isolines in the profiles drawn from maps compiled at different time periods 
The distribution of depth distances from the shore show a frequent shift of 3,5 and $7 \mathrm{~m}$ depths towards the shore if compared to the situation in 1875. More significantly the bottom slopes became steeper south of the southern pier. The bottom became slightly flatter only as far as the $2 \mathrm{~m}$ depths. Moreover, sediments migrating along the shore were considerably more accumulating at the $10 \mathrm{~m}$ isobath that, both north and south of the harbour, shifted westwards by about 150-200 m (see Table). Hence, the longshore drift began passing by the harbour gate, while the channel mouth framed by piers concentrated the seaward flow of water and increased spreading of sediments in outer areas more remote to the shore.

The approach of points of 3, 5 and $7 \mathrm{~m}$ depths, which were earlier at the southern bar shallow, closer to the shore shows the bottom erosion started. Instead of a shallow marked in 1913, one can see nearly parallel isobath ramming directly into the southern pier. At the same time, the shoreline beside the southern pier shifted eastwards. The seaward tip of the southern pier reached even $870 \mathrm{~m}$ from the shoreline when in 1875 it was just $357 \mathrm{~m}$. So, the tip of the pier stood out to sea by a distance similar to that determined by E. Červinskas as an elongation of the southern pier, while the real augment of the shore reached here 78 metres. Similar tendencies also prevailed at the northern pier, where the distance from the shore as far as the distal end of the hydro-engineering structure increased from 212 to 270 metres. The gradient of the nearshore slope in the zone from 3 to $5 \mathrm{~m}$ depths is most increased within the shore length at $55^{\circ} 39-40^{\prime} \mathrm{N}$, where the 3 and $5 \mathrm{~m}$ depths are, respectively, at the distances of only $150 \mathrm{~m}$ and $225 \mathrm{~m}$ from the shore (Fig. 11).

\section{DISCUSSION}

Such increase in the slope gradient close to the shore is not necessarily related to the erosion processes. The map indicates that there were distinct underwater bars and troughs in the nearshore 5-6 km south of the harbour.

Changes in distances of certain depths from the shore not only affect qualitatively the area of litho- and morpho-dynamic processes, but also reflect the amount of sediments accumulated on the underwater slope of the nearshore. Applying some assumptions it is possible to approximately calculate the value of changes in distances to certain depths for 1 metre of a shore length. So, a change in a distance to the depth of 2 metres from 200 to 400 metres gives additional increment of sediments equal to $116 \mathrm{~m}^{3} / \mathrm{m}$; while a similar change of a distance to the depth of 3 metres from 200 to 400 metres gives the increment of about $288 \mathrm{~m}^{3} / \mathrm{m}$. A shift of the $5 \mathrm{~m}$ depth mark gives additional $783 \mathrm{~m}^{3} / \mathrm{m}$, and when a $7 \mathrm{~m}$ depth distance changes from 600 to $900 \mathrm{~m}$, $1171 \mathrm{~m}^{3} / \mathrm{m}$ of sand accumulates in the whole zone of the changes. Even higher changes in sediment volumes (up to $3883 \mathrm{~m}^{3} / \mathrm{m}$ ) are created by a seaward shift of $10 \mathrm{~m}$ depth distance from 900 to $1980 \mathrm{~m}$.

These calculations, of course, can have a rather significant error, depending on the geological character of the bottom and the peculiarities in sediment balance, but they enable to get at least an approximate knowledge that only a northward or southward shift of a bar shallow can additionally bring into the litho-dynamical processes the sediments of about $15 \mathrm{mln} . \mathrm{m}^{3}$ or stabilise them.

\section{CONCLUSIONS}

The olden cartographic documents provide information about the peculiarities in relief and lithodynamics of the nearshore before the active human impact began.

The map compiled by J. W. Suchodoletz in 1743 reflects the bottom relief that was formed under the following conditions: 1 - rich alimentation with sand drift from the eroding shores of the Sambian Peninsula; 2 - intensive transport of sand from the underwater part of the slope to the above-water zone of the shore and further by wind to the large dune ridge of the Curonian Spit. In the 18th century, the major part of the sand spit as well as the nearshore part north of the Klaipeda channel was within the zone of active transit of the longshore drift. The sediment transit reached the maximum intensity at the northern part of the Curonian Spit, where high bars with very deep troughs had been formed. The priority accumulation of 
the sediments prevailed only north of the Klaipeda channel. The mouth zone of the channel had not hindered the circulation of the sediments along the shore.

Another map compiled in 1855 reflects the situation in the nearshore at the start of formation of the so-called protective beach dune ridge and the stabilisation of Klaipeda channel shores. These works basically limited further northward formation of the Curonian Spit and made the southern bar shallow more manifested. The accumulation of sediments got more intense for several kilometres in both directions from the channel.

The 1875 map of the nearshore relief shows the intensified accumulation of sediments by several kilometres south of the southern pier and a retreat of the shoreline at the pier itself. At that time, the tendency of erosion bay showed up north of the northern pier. The sediments still easily had passed by the piers and alimented the sea nearshore north of Klaipeda. A cross bar shallow had been formed in front of the harbour gate with 5-6 $\mathrm{m}$ depths, while large bar shallows were being formed farther north.

The map compiled in 1913 reflects the nearshore relief when the construction of outer hydro-engineering structures of the port had been finished. The information has been traced from this map about the general accumulation of sediments south of the harbour and the erosion of the shore and bottom close to the southern pier, as well as the evolution of the northern bar shallow and tendencies in formation of an erosion bay north of the harbour.

The analysis of the historical cartographic documents about the sea shore zone relief allows to make a conclusion that the nearshore bottom least affected by human activities is seen in the 1743 map that can be used as a reference point for assessment of further changes.

\section{ACKNOWLEDGEMENTS}

The authors express their gratitude to Dr. Eduardas Červinskas for his kind permission to use maps from his personal archives.

Received 8 November 2015 Accepted 18 January 2016

\section{References}

1. Bagdanavičiūtė I., Kelpšaitè L., Daunys D. 2012. Assessment of shoreline changes along the Lithuanian Baltic Sea coast during the period 1947-2010. Baltica. 25: 171-184.

2. Bitinas A., Žaromskis R., Gulbinskas S., Damušyte A., Žilinskas G., Jarmalavičius D. 2005. The results of integrated investigations of the Lithuanian coast of the Baltic Sea: geology, geomorphology, dynamics and human impact. Geological Quarterly. 49: 355-362.

3. Červinskas E. 1959. Vandens apykaitos tarp Kuršiu marių ir Baltijos jūros klausimu. Geografijos metraštis. 1: 46-58.

4. Červinskas E. 1978. Kartografinio vaizdo raida [Development of cartographic view]. Iš: A. Rainys (ed.). Kuršiu marios. I dalis: Gamtinès salygos ir raida. Vilnius: Mokslas. 93-154.

5. Červinskas E. 1991. Klaipèdos sąsiauris. Mokslas ir gyvenimas. 8(406): 4-5.

6. Roedder H. 1908. Zur Geschichte des Vermessungswesen Preussens insbesondere Altpreussens aus der ältesten Zeit bis in das 19. Jahrhundert. Stuttgart: Wittwer. $191 \mathrm{p}$.

7. Hess von Wichdorf H. 1919. Geologie der Kurischen Nehrung. Berlin: Preussische Geologische Landesanstallt. $198 \mathrm{p}$.

8. Jarmalavičius D., Žilinskas G. 2006. Peculiarities of sand sorting on the Lithuanian coast of the Baltic Sea. Geologija. 56: 36-42.

9. Knaps R. 1952. Ograditelnye sooruzhenya tipa molov i dvizhenye nanosov na peschanykh poberezhyakh. Izvestiya AN Latviyskoy SSR. 6(59): 87130 [in Russian].

10. Knaps R. 1966. Peremechchenye nanosov u beregov vostochnoy Baltiki. Razvitye morskikh beregov $v$ uslovyakh kolebatel'nykh dvizheniy zemnoy kory. Tallinn. 51-59 [in Russian].

11. Korobova I. Ya. 1969. Iskluchitel'nyi shtorm 17-18 oktyabrya 1967 g. i ego vliyaniye na rezhym Klaypedskogo podkhodnogo kanala. Okeanologiya. 9(6): 82-66 [in Russian].

12. Korobova I. Ya. 1971. Deformacii rel'efa pribrezhnoy zony $i$ ikh vliyaniye na zanosimost' podkhodnogo kanala porta Klaypeda. Novye issledovaniya beregovykh procesov. Moskva. 90-102 [in Russian].

13. Zembrickis J. 2004. Klaipéda XIX amžiuje [Klaipeda in 19th c.]. II tomas. Klaipedda: Libra Memelensis. 208 p.

14. Žaromskis R. 1974. Povandeninių sèkliu reljefingumo klausimu (Kuršiu nerijos jūros priekrantès pavyzdžiu) [On the relief character of underwater bars (After an example of Curonian Spit marine nearshore)]. Geografijos metraštis [Geographical Yearbook]. 13: 229-235. 
15. Žaromskis R. 2007. Impact of harbour moles and access channels on the South-East Baltic shore zone. Geografija. 43(1): 12-20.

16. Žaromskis R. 2008. Baltijos jūros uostai [The Baltic Sea Ports]. Vilnius: Vilniaus universiteto leidykla. $431 \mathrm{p}$.

17. Žaromskis R., Gulbinskas S. 2010. Main patterns of coastal zone development of the Curonian Spit, Lithuania. Baltica. 23(2): 149-156.

18. Žaromskis R., Gulbinskas S., Visakavičius E. 2010. Mažųjų uostelių ịrengimo Lietuvos krante šiauriau Klaipėdos prielaidų analizè. Jüros ir krantų tyrimai 2010: konferencijos medžiaga. 219-224.

19. Žaromskis R., Gulbinskas S. 2011. Smèlio nešmenų migracijos ypatumai Baltijos jūros Lietuvos žemyniniame krante. Jūros ir krantu tyrimai 2011: konferencijos medžiaga. 272-276.

20. Žilinskas G. 1998. Kranto linijos dinamikos ypatumai Klaipèdos uosto poveikio zonoje. Geografijos metraštis. 31: 99-109.

21. Žilinskas G., Jarmalavičius D., Minkevičius V. 2001. Eoliniai procesai jūros krante. Vilnius: Geografijos institutas. 283 p.

22. Žilinskas G., Jarmalavičius D. 2007. Interrelation of morhometric parameters of the submarine shore slope of the Curonian Spit, Lithuania. Baltica. 20(1-2): 46-52.
Rimas Žaromskis, Saulius Gulbinskas

\section{BALTIJOS JŪROS LIETUVOS PRIEKRANTĖS DUGNO YPATUMU ATSPINDYS ISTORINIUOSE ŽEMĖLAPIUOSE}

Santrauka

Naudojant istoriniuose žemėlapiuose esančią batimetrijos informaciją analizuojamas Baltijos jūros Lietuvos kranto povandeninis šlaitas i pietus ir į šiaurę nuo Klaipédos uosto. Tam tikslui i metrinę matavimo sistemą buvo perskaičiuotos senosios gylių nuorodos, nubraižyti skersiniai priekrantès reljefo profiliai, o pagal juos sudaryti atstumo nuo kranto iki 3, 5, 7 ir $10 \mathrm{~m}$ gylio taškų grafikai. Analizuoti 1743, 1855, 1875 ir 1913 m. žemėlapių gylio duomenys. Šie laikotarpiai atitinka specifines kranto zonos morfodinamikos ir litodinamikos sąlygas. 1743 m. Kuršių nerijoje dar nebuvo apsauginio paplūdimio kopagūbrio, o iš kranto zonos smèli vèjas perpustydavo ị didžiųjų kopų volą. Klaipèdos uoste nebuvo įrenginių, kurie apsunkintų smèlio migraciją išilgai priekrantès. $1855 \mathrm{~m}$. sutvirtinti Klaipèdos sąsiaurio krantai, bet dar nebuvo uosto molų. 1875 m. baigti uosto molai ir iš dalies suformuotas apsauginis paplūdimio kopagūbris. 1913 m. iš esmès suformuotas apsauginis kopagūbris ir visu pajègumu èmè funkcionuoti Klaipèdos uostas, kurio vartų gylis - 5-6 metrai.

Daromos išvados apie kiekviename priekrantès raidos etape buvusi dugno reljefą ir jo kaitą lèmusias sąlygas. Tikimasi, kad kartografinès medžiagos panaudojimo principas taps atskaitos tašku jūros kranto zonos antropogenizacijos istorijoje.

Raktažodžiai: istoriniai žemèlapiai, dugno reljefas, jūros priekrantè, krantotvarka, hidrotechniniai įrenginiai, Baltijos jūra, Kuršių nerija 